\title{
Historical Poetics and the Register of History
}

In what way is 'Historical Poetics' historical?

At one level this is to ask: what is its history? If the 'Historical Poetics group' (HistPo) has mobilised a diverse array of thinkers into its matrix of questions in a short space of time - 'not an ideology, not a school, not a single methodology', ${ }^{1}$ as the group's description of its purpose has it this is not simply because of disciplinary trend-setting, but the way the discipline operates institutionally. One story we might tell is of historical poetics/the group emerging out of a crisis within 'New Historicism', which was deemed to have lost sight of the singularities and irreducibilities of literary language, and its supersession, at least where poetry scholarship is concerned, by two other 'News': the 'New Formalism' and the 'New Lyric Studies'. As a story of 'the discipline', it is fitting that both these 'News' should establish their institutional credentials through the same two of the major organs of American academe (MLQ and $P M L A)$. Each pitches itself not just as 'new', but as 'the new', ${ }^{2}$ hence making a hegemonic claim towards contemporaneity; ${ }^{3}$ each pitches itself quite overtly as an intervention into the current state of 'the discipline'.

But there is another set of institutional-historical conditions at work, not unconnected from these but nor in determinate relation to them: broader divisions of intellectual labour, ideologies of 
expertise, as well as the dispositions and distributions of the materials of thought, the technologies

which shape not just the methods and dissemination of research but what questions are posed, even what is conceived of as a viable object of study. It is hardly a surprise that the modishness of 'material culture' in Anglophone academe should coincide with the much-heralded dematerialisation of both labour and modes of production in increasingly 'post-industrial' economies; ${ }^{4}$ that histories of 'the book' should focus on the circulation of pamphlets, private manuscripts, letters, gazettes, at a time when digital technologies are so disruptive for the book trade and reading practices; that for academics whose intellectual life is increasingly conducted via email, writing on word processors and overwriting earlier drafts as they go, an author's surviving drafts and manuscripts, their handwriting, even blots on the page, should obtain such auratic allure. The contemporary injunction to be 'historical' thus itself needs to be historicised. With the shift in the 'materials' of scholarship there corresponds a shift in the 'material' bases of scholarly production. Suddenly the humanistic scholar can brandish tangible objects of study, and tangible 'outputs': objects to be digitised/disseminated, objects that provide a foundation for one's expertise at once fungible and falsifiable. At the same time, genetic criticism, or tracing the circulation of text through letters, pamphlets, periodicals, anthologies, textbooks in order to reconstruct a set of discourses, and even a 'literary culture'... this research is not cheap. Every institutional history is a story of the distribution of institutional resources. Empirical analysis of 'materials' will assuage the 
funding body, reassure all concerned that the humanities are something more than idle speculation;

but it will also attract the funding body: the expensiveness justifies the expense. In this sense it is noteworthy that the impulse for the Historical Poetics Group arose in large American state universities (Michigan, Rutgers), respected for research but hardly basking in endowments, on the cusp of the digital-archive transformation. A welcome irony here is that the institutional transfer of resources towards digitisation increasingly means that archival scholarship will no longer depend quite so heavily on a healthy travel grant. But this has a further consequence. As rare primary sources become increasingly available on databases and repositories, and a lexeme can be tracked and a history of word-usage told through word-searches on Literature Online and Google NGrams, historicism becomes the disciplinary expectation. 'Historical' is not a descriptive but normative epithet: its absence akin to professional negligence. Poetics is at the forefront of this, especially since the estimable Princeton Prosody Archive made centuries' worth of prosody manuals available to all. To be 'historical' is today, for an armchair prosodist like myself, the path of least resistance. The extraordinary institutional success of the Historical Poetics group thus coincides with a broader disciplinary moment: the era of the default-historicist. The default-historicist is 'historical' in two senses: in intellectual orientation, but also in being successfully 'disciplined' according to the current expectations. Such disciplining pervades the Historical Poetics Group 'About' page: 
Other scholars have used 'historical poetics' to mean the continuity of poetic forms over time, or micro specification of verse technique, or macro analysis of the ethnocultural history of poetry, or histories of reading, or the recovery of texts and poets seldom read in the present. We are interested in all of these approaches, but none is sufficient without a self-conscious and rigorous critique of the historical implications of our present assumptions. ${ }^{5}$

Being coded, the phrase 'other scholars' is only legible to the initiated (one form of 'disciplining'); its apparently capacious expression of 'interest' in fact signals a marking of territory, where the 'other scholars' are in one gesture appropriated and dismissed. But the terms also invite us to interrogate the conceptualisation of 'history' operative here. If what is required, in order to be truly 'historical', is 'a self-conscious and rigorous critique of the historical implications of our present assumptions', then who constitutes the 'we' of this 'our'? How does it relate to the 'we' of 'We are interested'? Are these 'present assumptions' really so universally shared, and how 'present' are they $?^{7}$ One of the fascinating tensions to strike this observer is that, on the one hand, the Historical Poetics group appears quite symptomatic of its disciplinary-institutional moment, operating according to a very contemporary model of institution-formation; yet on the other it is organised around an axiomatic need to think outside the sedimented reading practices that prevail in current 
critical and pedagogical models of poetry. It is not for nothing that HistPo arises to a large part out of 'Reception Studies', given that it is in reception histories, as Yopie Prins notes, that the very notion that the historian might enjoy a 'fixed vantage point' is most glaringly exposed as fiction. ${ }^{8}$ The group's critique of these 'assumptions' has been much debated elsewhere; ${ }^{9}$ in the following I wish to ask about the other two terms in the formulation: 'our' and 'present'. In particular, what might poems have to tell us about how the categories of 'our' and 'present' come about, in making intelligible a collective, and possessive, subject, and grasping its temporality?

To speak of 'historical poetics' invites ambiguity, insofar as the term 'poetics' can name both the practices of poetic making and the 'the terms through which we recognize, describe, and evaluate poems', as the 'About' page puts it. Yes, one must show critical vigilance as to the ways poems are theorised, are delimited as 'historical' objects of literary scholarship, but not at the expense of the poems' own agency, in and across history, and in excess of history. A poem is of course - like our default historicist - subject to historical conditions, be they 'material' or disciplinary-generic. ${ }^{10}$ But existing in history does not exhaust the modes of being historical, and history itself is shaped, and mis-shapen, by excesses and aporia in the material-discursive circuits which bind us in our historical moment. If poems constitute instances of 'historical making', then let us read this in both the objective and the subjective genitive: a making that takes place in history, and a making of history. 
By 'making of history' what I have in mind is less poetry as historical intervention than a

work of historicity: what is 'made' are modes of intelligibility under which phenomena can disclose themselves, and people grasp themselves, as 'historical', modes within which chronological relations can be grasped as correlation, correspondence, causation (or for that matter, coincidence), modes through which the coterminous might become the contemporary. This can take place through a thematisation of the 'historical' as something emerging from out of the everyday, yet never wholly distinct from it; or through the naming of historical epochs, and the synecdochal work through which one moment can come to stand for this epoch (as crystalisation, cross-section, exemplar); or through a shift from an individuated experience of historical being onto historicity as collectively binding. In the below I map these kinds of historicising work onto a tripartite understanding of the poem 'register' of history: as the poem (a) 'registers' history, internalises into its textures the ruptures and continuities of historicity; as it searches for (b) a rhetorical register in which to speak history, to raise experiences up to the historical, and in so doing establish its own saying as 'historical'; and as it composes (c) a register of history, that is, documents, bears witness, to historicity in process, and names this as 'history'. To think this register of history I will look in particular at one poem of W.H. Auden, initially titled 'Spain' but subsequently renamed 'Spain 1937'. If this is my 'example', it functions less as exemplum than as case study, in which these different modalities of historicity are in process and, crucially, put up for grabs. 


\section{$\underline{\text { To register the historical }}$}

What's in a semicolon? In 'Spain', the semicolon operates as the grammatical-temporal sign of ahistorical time. The poem opens with the claim 'Yesterday all the past'; in its gesture of sovereign dismissal, the phrase proffers a curious double temporality, which is at the same time a nontemporalisation: the longue durée is collapsed into a single day, and the single day distended into 'all the past'. The next four stanzas elaborate this as they enumerate what Edward Mendelson calls a 'grand synecdochal panorama': ${ }^{11}$ a series of verbless statements, each organised around an archetype, at once too concrete to be symbols and yet of indeterminate symbolic resonance. Each is separated by a semicolon: 'The language of size [...] the diffusion/ Of the counting-frame [...] the shadow-reckoning $[\ldots]$ the assessment $[\ldots]$ the divination $[\ldots]$ the invention $[\ldots]$ the taming $[\ldots]$ the bustling world $[\ldots]$ the abolition $[\ldots]$ the fortress $[\ldots]$ the chapel $[\ldots]$ the carving $[\ldots]$ the trial [...] the theological feuds [...] the Sabbath of Witches. ${ }^{12}$ Unlike either the comma or the colon, the semicolon does not imply subordination, be it causal, temporal, ideational; it serves as the punctuation marker of parataxis over hypotaxis. As such, it seems peculiarly apposite for a world where agency, causation, progression, are null. 
'Yesterday all the past' registers as an everydayness that unfolds through its non-

temporalisation; we attain authentic temporality by becoming historical; such authentic temporality

first discloses itself through a fissuring of the everyday:

The trial of heretics among the columns of stone;

Yesterday the theological feuds in the tavern

And the miraculous cure at the fountain;

Yesterday the Sabbath of Witches; but to-day the struggle.

With 'but to-day the struggle', something like historical experience first becomes available: an ordering of lived time, characterised by its intelligibility, its forward progression, anticipating 'Tomorrow, perhaps, the future'. We stand now not just as subject to history, but as subjects of history. In the word 'but', Auden would be registering historicity in process, as it fissures the grammar of the everyday.

In this regard, it is notable that the separation between the 'yesterday' of tenseless continuation and the 'to-day' of historical struggle is also initially marked by a semicolon. The advent of historical temporality retains the same grammar that had characterised the everyday's non-temporalisation. The next two assertions of 'But to-day the struggle', by contrast, are preceded 
by full-stops: they now indicate a more fundamental break with the past. After the third instance, we find the first indicative verb of the poem: fittingly, 'As the poet whispers'. However tentative, it is the poet-archetype that sets historical agency in motion, their whisper a minor disturbance of time.

Or set of disturbances - note the multiple temporalities 'As' acquires as relative pronoun, temporal conjunction, antecedent adverb, incurring temporalities of subordination, succession, simultaneity, but also of equivalence, of simile... 'Spain' registers history in its grammar, and in so doing appears to posit a quasi-Messianic 'History': a site of human agency, but also a 'purposive force', obeying its own laws. ${ }^{13}$

That 'Spain' should on the face of it chart this emergence of 'History' would fit with another kind of historical work the poem was deployed by its author to undertake. Published as a single pamphlet in April 1937, shortly after Auden had returned from a brief stint as an ambulance driver for the International Brigade, it was a public act of awareness-raising, and fundraising, with its royalties donated to the charity Medical Aid for Spain. It would thus be natural to read 'Spain' as a continuation of the peroration to Auden's New Statesman article two months earlier: 'a revolution is really taking place, not an odd shuffle or two in cabinet appointments. In the last six months these people have been learning what it is to inherit their own country, and once a man has tasted freedom he will not lightly give it up.' ${ }^{14}$ The poem would register this 'revolution', but also situate it in a longer speculative history and identify the advent of 'History' in 'the struggle'. Mindless 
consumerist behaviour ('our faces, the institute-face, the chain-store') metamorphoses into a sudden

'blossoming'; solidarity effects the transformation of 'tenderness into a people's army'. The

semicolon, indicating the porosity between the everyday and an authentic historical consciousness,

would be a marker of political optimism, a hope that poems might (to borrow Auden's terms from two years later) be not merely a 'product' of history but its 'cause'. ${ }^{15}$

But that porosity goes both ways. If the disturbance takes place within the very grammar of the everyday, this would intimate that the everyday continually inheres the possibility of rupture: disturbances which at first might appear indiscernible from the texture of the everyday but which fissure into epochal transformation, an aporetic opening-up of this texture from within its own grammar. But with this comes a certain reversibility, in which historical subjectivity is never wholly extricated from its inauthentic everydayness. We have never, strictly speaking, been historical.

This is certainly the indication one gets from a second level at which 'Spain' registers history: the figural. When 'the poor' call out 'O show us/ History the operator, the/ Organiser, Time the refreshing river', what matters is less how History shows itself than that it show itself at all. In this, the poem's registering of history is bound in a logic of prosopopoeia, again awkwardly suspended between literal and symbolic: 'O descend as a dove or/ A furious papa or a mild engineer: but descend.' This reaches crisis point in the response given to 'the poor', not by 'History' but by 'the life, if it answers at all'. Does 'the life' stand in for History? Is it able to speak for 
History? What are we to make of the possibility that 'the life' does not answer? This is followed by further slippage of archetypal figures: 'To you I'm the/ Yes-man, the bar-companion, the easilyduped'. The poem registers history through, even as, this slippage, effecting a porosity of figural identities that would complement those of its grammar: neither eruption out of the everyday, or irruption into the everyday, but a radical immanence of historicity in the everyday, textured as striation, aporia, rupture.

The poem as historical intervention is thus in contradiction with its thinking, registering, of history. Its work of history is undercut by its work of historicity. ${ }^{16}$ This somewhat complicates Auden's subsequently repudiation, not only of his earlier political commitment, but of 'Spain' itself. Retitled 'Spain 1937' and subjected to extensive revisions in the 1940 collection Another Time, it was eventually excised from Auden's body of work altogether, dismissed by its author as 'trash' ${ }^{17}$ Probably the most notorious change is the alteration of the phrase 'The consious acceptance of guilt in the necessary murder', partly prompted by George Orwell's criticism that the phrase 'could only be written by a person to whom murder is at most a word'. ${ }^{18}$ Auden would years later defend the phrase with a rather unconvincing syllogism - 'To kill another human being is always murder; In a war, two sides murder their opponents; If a war can be said to be just, then murder is in some cases necessary' ${ }^{19}$ - but in 1940 replaced the offending phrase with the more neutral 'fact of murder' ${ }^{20}$ Yet there is an instability to the 1937 version's apparently positivistic 
assertion - murder is both 'necessary' according to the demands of 'History', and always gratuitous

- that the revisions dissolve: in its very articulation of historical agency, the viability of such agency

unravels.

However, here too the densest registering of history takes place at the level of punctuation.

When the semicolon before the first 'But to-day the struggle' is in the 1940 text replaced with a

full-stop, this entails a radically different thematisation of the ruptures and continuities of history.

The full-stop signals the ordered break from the everydayness of yesterday - something registered

prosodically as it elongates the caesura between 'Yesterday the Sabbath of Witches' and 'But to-

day the struggle.' In the 1937 version, the epochally transformative lies immanent within the

everyday; in the 1940 version, the porosity between everydayness and authentic historical

experience is sutured, and thereby regulated. Something similar is at work in an apparently opposed

revision. Whereas the timeless present that preceded 'the struggle' was enumerated with

semicolons, the speech given by 'History'/‘the life' was in the 1937 version itself arranged by

colons: as paratactic succession is replaced by hypotactic subordination, it would appear that,

grammatically at least, History is indeed the 'organiser', endowing temporality with coherence. In

his 1940 revision he replaces these colons with semicolons, which would retract the possibility of

such a distinct form of organisation, or at least underplay the distinctiveness between the register

through which 'the life' speaks and that of the everydayness of 'the past'. ${ }^{21}$ 
In one instance, the 1940 revision excises the semicolon and in so doing sets up a neat break between the everyday and History; in the other, it introduces the semicolon and thereby denies History its grammar of ordering, the very thing that would distinguish it from the everyday. The one insists on the radical exteriority of History, the other on its indistinctiveness. Both revisions, however, retract the speculative account of history that the 1937 version had proposed, which pits the historical against the everyday, yet leaves the relation between the two porous and unstable.

Auden's dense workings of the relation between historicity and the everyday should give us historical poeticians pause. Thinking through the era that succeeded the purported 'End of History' with a War on Terror and then a financial crash, Lauren Berlant identified a specific experience to living in a 'historical present', opposing this to 'everydayness'. For Berlant, this experience was characterised by a 'disturbed time' in which 'the atmosphere suggests a shift of historic proportions in the terms and processes of the conditions of continuity of life. ${ }^{22}$ The temporal-figural slippages that 'Spain' charts would both corroborate and complicate such an account: what is disturbed by 'disturbed time' is not just everydayness, but the schema of the historical-everyday opposition itself, and 'Spain' is less than sanguine as to our affective ability to identify such disturbances. Where Berlant thinks historical time in its lived phenomenology, with being-historical a qualitatively singular affective state, the logic of prosopopoeia operative in 'Spain' makes the issue of identifying personhood more fraught, as though to ask: how can we know, and how can we trust, 
what we are feeling? But no more is 'Spain' willing to give up entirely on historical agency, or what Henri Meschonnic has called 'the indefinite faculty for presence in the present, for transformation of all presents. ${ }^{23}$

Meschonnic's argument is that the 'historicity' of discourse lies in the fact that each instance of discourse is effectively a transformation of discourse: language is historical not by virtue of being embedded in past uses, structures, or genres of language, but as it continually opens up new possibilities for self-articulation. As for Berlant, this involves a complex interplay of continuity and rupture: to be 'historical' is not simply to exist in history but to depart from it, to set in motion alternative historical currents latent in a pre-existing conjuncture. But how are we to grasp such a process within poems, or in the interactions between individual poems and the circuit of texts, discourses, ideologies, the praxes of reading, writing, reviewing, parodying, pastiching, categorising, taxonomising, teaching... everything that could be included in what Prins has called 'the discursive arrangements that made poems possible from the inside out'? ${ }^{24}$ This poses a double challenge: to re-embed poems within these arrangements, which requires reconstructing the arrangements themselves; but also to trace how individual oeuvres, repertoires, poems, or individual expressive gestures might, for all their embeddedness in their particular moment, exceed this moment - the histories that they conceptualise, sketch out, gesture towards, set in motion, often (as in the case of 'Spain') in spite of themselves. This entails listening to what the poems have to tell us 
about their historicity. Yes, we need to be alert to retroprojecting 'our present assumptions' about poetry onto poems from other epochs, but we need to be just as alert to retroprojecting models of history onto them. It would be a sad irony indeed if our 'historical poetics' ended up defusing their excesses over their historical conjuncture - and indeed, the plural historicities they might open up.

\section{'Our present'}

This leads to a certain discomfort with an - admittedly provocative - proposal Prins makes in her contribution to the PMLA special issue on The New Lyric Studies. Discussing Sidney Lanier's Science of English Verse, Prins argues that historical poetics is not concerned with the 'practical application' of Lanier's conception of scansion:

There are other, more interesting questions. What response did Lanier get from his contemporaries, and can we read his ideas about sound in relation to nineteenthcentury theories of acoustics and music or alongside other essays on prosody, like Edgar Allen Poe's 'Rationale of Verse' or Coventry Patmore's ‘Essay on English Metrical Law'? How did these metrical debates contribute to Anglo-American literary culture, and what were the political and philosophical stakes of thinking about prosody? Although a New York Times review of The Science of English Verse 
complained that 'we are somewhat in danger of being "scienced" to death', what

kinds of knowledge or ways of knowing are implicit in Lanier's claim to

'science'?'25

The rhetoric of 'interesting' is another form of disciplining: anyone turning to Lanier for insights into reading poems today is, tacitly, 'boring'. But it is also a methodological claim: that Lanier's thinking can only make sense within its historical moment: to historicise is necessarily to contextualise. Yet the context itself is subsequently rather mobile, shifting from Lanier's 'contemporaries' to 'the nineteenth century' as a whole, to 'Anglo-American literary culture'. It is one thing to demand that we scrutinise 'our present assumptions', but here Prins would suggest that the afterlives of a poet-theorist across epochs are not the proper concern of 'historical' poetics. Historicism comes across, on this model, as a means of consigning its objects firmly to the past. ${ }^{26}$

This same gesture is at play when Auden renames 'Spain' as 'Spain 1937': it denotes a particular moment, now gone. Reducing the poem to a historical document inoculates its readers from those earlier aspirations. This does not simply apply to its status as historical intervention: the attempt to trace an impersonal, purposive force of 'History' becomes the symptom of that historical moment, now gone - and at the same time now stands as definitive of that moment. In this sense, Auden is not simply consigning his poem to the past but offering an alternative registering of 
history: no longer concerned with grasping the emergence of the historical from out of the everyday, or thematising the fraught relations between historicity and everydayness, the poem-assymptom characterises what was historically determinant about that moment. In this regard, 'Spain 1937 ' resembles the title '1 September 1939' - the poem habitually taken to signal Auden's departure from his commitment to a historical vocation for poetry. Here, the date becomes its mode of registering history: its synecdochal snapshot of its New York dive bar, the day Nazi forces invaded Poland, commemorates this moment as historical, just as it appears that history is happening elsewhere. Giving name to this date, the poem endows it with historicity: that is, engenders parameters of intelligibility according to which something like a 'historical moment' might be brought into view as a coherent section of time. It does not merely register history, but becomes a register of history: an act of naming that delineates epochs, identifies the communal subject of history, and the modality of their community.

Seeking to name an epoch, Auden's project once again overlaps with that of the historical poetician. There is a striking phrase in the opening to Meredith Martin's The Rise and Fall of Meter as she justifies her time bracket of 1860-1930: 'Usually read as a transition between the Victorian and Modernist eras, the period between 1860 and 1930 is a crucial epoch in its own right. ${ }^{27}$ Martin distinguishes between 'era', 'period', and 'epoch': 'era' seems to be an institutional construct ('Victorian' and 'Modernist' as categories around which pedagogy and research are organised, 
categories which bear an uneasy truce between Zeitgeist and chronology), and 'period' seems purely to do with dates, whereas 'epoch' is more fluid. It is in establishing an epoch that the historical work is taking place, Martin implies, for the 'epoch' will subsequently provide a framework within which certain trends, correlations, become historically salient, able to be fleshed out as intelligible forms of relation. One might compare this to Prins's justification of the term 'Victorian' in Victorian Sappho, a work whose 'a recursive structure' serves the critical role of exacting a 'more complex reading than straightforward sequential analysis. ${ }^{28}$ The title, Prins notes, 'invoke[s] Victoria alongside Sappho, in order to name the second half of the nineteenth century as a time when feminine figures and figurations of femininity contribute in complex ways to the formation of aesthetic categories, and more generally to the feminization of Victorian culture' ${ }^{29} \mathrm{We}$ all know that such carvings-up of historical time are heuristics, and yet their longstanding institutional dominance has endowed them with ideological, if not ontological, reality.

In this sense, Auden's attempts to name his own epoch become particularly revealing. ' 1 September, 1939' grasps its eponymous date as the culmination of a 'low dishonest decade' (anticipating another epochal epithet, when the immediate postwar years are branded 'the age of anxiety'). That 'decade' should be the first rhyme of the poem (in line 5, rhyming back to line 3), and hence the first hint of a rhyme scheme, only intensifies its naming force. The poem 'makes' history not by intervening but by naming. The decade is then situated within a broader historical 
sweep which unseen binds together Martin Luther with Hitler's childhood in Linz, the fragility of democracy as documented by Thucydides with that of the Weimar Republic, and the major modernist shocks of Nijinsky and Diaghilev with the skyscraper as imperialist overtaking of the sky. A historical naming and a naming of history: '1 September 1939' would name the very history to which it is subject. As in 'Spain', history is grasped as both continuity and rupture; each sees the historical as a rupture in the everyday. And as in 'Spain', the naming of history necessitates a specific temporal-rhetorical register, which suspends the archetype and the particular, the symbolic and the literal. To register the historical means both to construct a register of history, to document the historical as it takes place, but also to articulate a register in which this naming can take place. In its work of historicity it would set in motion the conditions of intelligibility that determine what counts as a historical relation.

Yet there are crucial discrepancies between the two poems. There is no little irony that 'Spain', despite purportedly standing as a call to arms, should eschew the 'light' forms (blues, ballad, dolnik, refrain) that Auden predominantly employed during this period. Its prosodicgrammatical complexity, the slippages between literal/symbolic, between different orders of imagery, so integral to its historical thinking, are antithetical to any direct historical intervention; ' 1 September, 1939' by contrast, finds a readymade community both in its vernacular sensibility and its embeddedness in a legible tradition - even as Auden casts off the poet's civic vocation, and says 
the poet 'speaks to private individuals'. ${ }^{30}$ This is most clearly embodied in the poem's adoption of the verse line from Yeats's 'Easter 1916', though this choice is undercut by its scepticism towards the nation-building aspirations, not to mention rhetorical confidence, of its model. Yeats finishes by predicting the success of his own poetic utterance as it is taken up by others: 'I write it out in a verse [...] Wherever green is worn', ${ }^{31}$ Auden, by contrast, merely offers an optative 'May I [...] Show an affirming flame'. Yet this does not mean a retreat from the historicising role of the poet.

One of the reasons that Auden at this period employed so many 'light' verse forms was that, as he put it in his introduction to The Oxford Book of Light Verse, 'The problem of the modern poet, as for everyone else to-day, is how to find or form a genuine community. ${ }^{32}$ This is very much the predicament of the poet-figure 'Uncertain and afraid' at the dive bar on Fifty Second Street. The 'Waves of anger and fear' to which he is subject are 'Obsessing our private lives' (my emphases): this is a 'we' united by the condition of each being a private individual, something reinforced when he writes that 'the normal heart' craves 'Not universal love/ But to be loved alone', and that each of us is 'made of Eros and dust'. ${ }^{33}$ The locution 'I and the public' (which anticipates another New York memorialising poem, O’Hara's 'The Day Lady Died', where 'everyone and I stopped breathing, ${ }^{34}$ ) grasps this uneasy community well, and also the uneasy civic place of the poet, both participant and documenter. The poet is not just one more civilian, but, despite the poem's own avowed ethos, an exemplary figure, tasked with negotiating between the lived experience of the 
individual subjected to History, and a collectively binding historicity. Articulating a community of individuals, collectively inhabiting a historical moment, and thereby naming both community and historicity into being, '1 September 1939' is perhaps the poem of Auden's that best fits the model of Shelley's deeply embarrassing (and embarrassingly enduring) 'unacknowledged legislators of the world'. ${ }^{35}$

\section{The dustbin of history}

Auden renamed 'Spain' 'Spain 1937', and eventually disowned the poem altogether; in 1967 he described '1 September, 1939' as 'the most dishonest poem I have ever written' ${ }^{36}$ The two of his poems I have cited as peculiarly exemplary for the ways they register history are the two their author singled out as aberrant. It is a commonplace for readers of Auden to lament the disavowal of his earlier aspirations, or his revisionist treatment of his own biography; yet it strikes me that this is in certain ways an extension of the historical thinking these poems perform. For a start, Auden's revisionist autobiography would organise its narrative around a coherent, tangible transformation (some time in late 1938/early 1939) in his understanding of what a poet is and does - replaying his model of history as 'cataclysm' from earlier that decade. One of the earliest attempts of this is a vignette, at once flippant and sincere, from early 1940: 
In the Munich crisis I listened to the radio with a happy excitement, secretly hoping there would be a war, a hope for which I found excellent political reasons. This September, whenever I listened to the radio I started to cry. My attitude had changed because the personal problem which in 1938 was still unsolved and which in despair I was looking to world events to solve for me, was solved this year. ${ }^{37}$

In Auden's self-diagnosis - he fell in love, and anti-Fascism lost its urgency for him - lies a tacit claim about human motivation. It is not simply that sentimental fulfilment depoliticised Auden; it provided a framework in which he could retrospectively depoliticise his earlier politics. Such a narrative is tendentious, of course: it occludes the internal tensions within each poem, not to mention the vacillations which score his various statements from the period on the historical tasks of, variously, poetry, art, literature. ${ }^{38}$ Writing to Classics scholar E.R. Dodds shortly before his departure for Spain, Auden explained: 'I am not one of those who believe that poetry need or even should be directly political, but in a critical period such as ours, I do believe that the poet must have direct knowledge of the major political events. ${ }^{39}$ Such 'direct knowledge' in a 'critical period' implies that poetry offers a medium for truth-telling in an age of misinformation. And whilst in 'The People v. the Late Mr William Butler Yeats', his Defence Counsel argues that the fact that art never re-enters history as 'effective agent' means that 'the question whether art should or should not 
be propaganda is unreal', this claim is bookended by his description, in October 1938, of André

Malraux's novel Days of Hope, set amongst the combatants on the Republican cause against Franco

in Spain, as 'propaganda - propaganda for the truth', ${ }^{40}$ and the statement of pared-down poetic

vocation in the eighth stanza of ' 1 September, 1939', his testament to that month when listening to

the radio reduced him to tears: 'All I have is a voice/ To undo the folded lie'. ${ }^{41}$

Auden's retraction of his commitment to(?) the historical work of poetry is in this sense

itself a form of history-making. And, in two crucial ways, this history-making is determinant for our current historical, disciplinary, moment. First, in the claim given by the Counsel for the Defence in 'The People Versus the Late Mr William Butler Yeats', which ends: 'But there is one field in which the poet is a man of action, the field of language... ${ }^{42}$ When Rachel Galvin writes that

A poem written during wartime is not likely to 'stop the war,' as Auden writes. It may not even predict an outcome or offer correctives to the statements that appear in the press. But it may announce its own motives and work to expose the problems inherent in linguistic expression ${ }^{43}$

poetry's capacity to 'expose the problems inherent in linguistic expression' makes it a political mode in its own right, with Auden an unlikely precursor to a Left poetics that will encompass, inter 
alia, Adorno, Kristeva, and the 'Language' poets, and today is surely the dominant critical model

for political poetry.

But most pertinent for the question of 'historical poetics' is another claim from the Defence

Counsel: 'Art is a product of history, not a cause. Unlike some other products, technical inventions

for example, it does not re-enter history as an effective agent' ${ }^{44}$ The notion of 'history' promoted

here is no doubt valid enough, in as far as it goes, but it doesn't go very far. Auden's poems exhibit

a historising agency irreducible to the product-cause opposition: to make history is not the same as

to cause it; to task something with 'causing' history presumes that history is pre-made; in the

making of history, what is up for grabs is the question of what history is, and can be.

Auden's attempts to place his poems firmly in their era operate through an act of

contextualisation which, far from returning them to their 'historical moment', reveals itself to be an

act of dehistoricisation. Consigning the poems to the past, refusing their ability to exceed their

historical moments, to open up new temporalities, leaves history itself an inert object of knowledge

rather than something that is ceaselessly being reworked, remade. Auden's Defence Counsel is the

very exemplar of the twenty-first century default-historicist, inhabiting a world of historical

products, resistant to hearing the modalities of historicity the poems themselves would be opening

up. To be rigorously, self-consciously alert to 'our current assumptions' is salutary, and necessary but not sufficient unless we also expose ourselves to the different historicities opened up by a 
poem's historical making, historicities the poem may subsequently inhabit as so many afterlives,

and through which it remains, always anew, historical.

\footnotetext{
${ }^{1}$ See http://www.historicalpoetics.com/about (accessed 27 April 2018).

${ }^{2}$ Marjorie Levinson ('What is New Formalism?', PMLA 122:2 (2007), 558-69) studiously avoids this 'the', but Susan Wolfson ('Reading for Form', MLQ 61:1 (2000), 1-16) does identify it as a 'the' (8). The PMLA special issue (123:1 (2008)) is more open in its aspirations, titled as it is The New Lyric Studies.
}

${ }^{3}$ There is, however, some circumspection on this front among the contributors. 'Lyric studies has been new before', begins Rei Terada, and Levinson also notes that many 'new formalists' are wary of the epithet (568). See Rei Terada, 'After the Critique of Lyric', PMLA 123:1 (2008), 195-200 (195).

${ }^{4}$ See Maurizio Lazzarato, 'Immaterial Labor', in Paolo Virno and Michael Hardt, eds, Radical Thought in Italy: A Potential Politics (Minneapolis: University of Minnesota Press, 1996), 142-57.

${ }^{5}$ http://www.historicalpoetics.com/about

${ }^{6}$ Presumably those alluded to are Boris Maslov, Simon Jarvis and Marlina Tarlinskaya, Alexander Veselovsky, 'reception studies', and the various recuperative works discussed in the opening remarks to Virginia Jackson and Yopie Prins's 'Lyrical Studies' (Victorian Literature and Culture 27:2 (1999), 521-30).

${ }^{7}$ Interestingly, Jonathan Culler's account of lyric also proceeds through a critique of current poetry pedagogy. Where Jackson and Prins see all poetry now as being grasped through the prism of 'lyric' self-expression, Culler sees lyric as suffocated by the dominance of the dramatic monologue, and a more general hegemony of narrative in all literary pedagogy. See Jonathan Culler, Theory of the Lyric (Harvard University Press, 2015), esp. 109-16. In their 'General Introduction' to The Lyric Theory Reader (Baltimore: Johns Hopkins University Press, 2015), Jackson and Prins invoke 'our current thinking', which they qualify capaciously as 'primarily literary criticism that has proven influential for AngloAmerican readers and poets both inside and outside the academy in the past century' (2).

${ }^{8}$ Yopie Prins, Victorian Sappho (Princeton University Press, 1999), 246.

${ }^{9}$ See for instance the introduction to the special issue on 'Historical Poetics' for Modern Language Quarterly 77:1 (2016), 1-12; Virginia Jackson and Yopie Prins, 'General Introduction' to The Lyric Theory Reader, 1-8; Simon Jarvis, 'What is Historical Poetics?' in Jason Potts and Daniel Stout, eds, Theory Aside (Durham: Duke University Press, 2014), 97-116; Yopie Prins, 'What is Historical Poetics?', Modern Language Quarterly 77:1 (2016), 13-40; Jonathan Culler, Theory of the Lyric, esp. 83-4. 
${ }^{10}$ One of the most compelling implications of Jackson and Prins's 'Lyrical Studies' is an analogy between the discipline as a condition of legibility for intellectual production, and the genre as condition of legibility of literary production, as 'lyric' shapes not just poems lyricising themselves, but later scholars reading them as 'lyrics'.

${ }^{11}$ Edward Mendelson, Early Auden (London: Faber, 1981), 316.

${ }^{12}$ W.H. Auden, Selected Poems, ed. Edward Mendelson (London: Faber, 1979), 51-5. Auden does, however, employ fullstops in place of semicolons at the end of stanzas.

${ }^{13}$ Mendelson, Early Auden, 304.

${ }^{14}$ W.H. Auden 'Impressions of Valencia', New Statesman, 30 January 1937, in The English Auden, ed. Edward Mendelson (London: Faber, 1977), 361.

${ }^{15}$ W.H. Auden, 'The People versus the Late Mr William Butler Yeats', in The English Auden, 393.

${ }^{16}$ This is the source of Cary Nelson's frustration with the poem, which for him makes it complicit with the new-critical aesthetic norms that valorise ambivalence. 'Spain' becomes 'the ideal political poem' precisely because it is 'tortured by the impossibility of making a clear commitment to either side in an imperfect world..' See Cary Nelson, Repression and Recovery: Modern American Poetry and the Politics of Cultural Memory (Madison: University of Wisconsin Press, 1992), 44. My own sense is that this is less an ideology of political indecision than an attempt to grasp the incompatible demands of thinking historicity.

${ }^{17}$ Robin Skelton, Poetry of the Thirties (Harmondsworth: Penguin, 1964), 41.

${ }^{18}$ George Orwell, 'Inside the Whale', in Collected Essays (London: Secker and Warburg, 1961), 118-59, 146.

${ }^{19}$ Letter to Monroe K. Spears, 11 May 1963, in Spears, The Poetry of W.H. Auden: The Disenchanted Island (Oxford University Press, 1963), 157.

${ }^{20}$ Auden, The English Auden, 212.

${ }^{21}$ This gives the lie to Mendelson's rather offhand assertion that 'Unless corrected by editors, [Auden] invariably used a semicolon where conventional usage requires a colon: to introduce further matter' (Early Auden, 326). The revisions show exactly how much grammatical-historical force is placed upon the semicolon, and how intricate Auden's own punctuation choice is, on this occasion at least.

${ }^{22}$ Lauren Berlant, 'Thinking about Feeling Historical', Emotion, Space and Society 1 (2008), 4-9 (5).

${ }^{23}$ Henri Meschonnic, Pour sortir du postmoderne enfin (Paris: Klincksieck, 2009), 18 (my translation).

${ }^{24}$ Prins, “"What is Historical Poetics?”, 37.

${ }^{25}$ Yopie Prins, 'Historical Poetics, Dysprosody, and The Science of English Verse', PMLA 123:1 (2008), 229-34 (233).

${ }^{26}$ This seems a retreat from her account of 'metalepsis' in Victorian Sappho - 'a temporal inversion casting a vision of the future into the past and a vision of the past into the future', as she puts it (135). In Victorian Sappho the 'metaleptic logic' endures to this day (246), less a fault to be corrected than a condition of reading in and across history. 
${ }^{27}$ Meredith Martin, The Rise and Fall of Meter (Princeton: Princeton University Press, 2012), 1.

${ }^{28}$ Prins, Victorian Sappho, 15, 246.

${ }^{29}$ Prins, Victorian Sappho, 15.

${ }^{30}$ Cited in Lucy McDiarmid, Saving Civilisation: Yeats, Eliot, and Auden Between the Wars (Cambridge: Cambridge University Press, 1984), 90.

${ }^{31}$ W. B. Yeats, The Poems, ed. Daniel Albright, rev. edn (London: J. M. Dent, 1994), 230.

${ }^{32}$ Auden, The English Auden, 367

${ }^{33}$ This reminds one of John Wilkinson's eloquent phrase: 'Our nature is my greatest privacy, and this is the silly and sustaining paradox, that the most idiosyncratic and inadmissible is the most deeply shared.' See John Wilkinson, 'Cadence' (1986), in The Lyric Touch (Cambridge: Salt, 2007), 143-8 (144).

${ }^{34}$ Frank O'Hara, The Collected Poems of Frank O'Hara, ed. Kenneth Koch (Berkeley: University of California Press, 1995), p. 325 .

${ }^{35}$ footnote

${ }^{36}$ Cited in Burt, "“September 1, 1939” Revisited', 539.

${ }^{37}$ W.H. Auden, 'Poet and Politician', January 1940. In Auden, Prose II, 41.

${ }^{38}$ It is not for nothing that 'The People v. the Late Mr William Butler Yeats' is framed as a dialogue, even if critics have almost exclusively aligned Auden's own position with the Defence Counsel: it provides the articulation of his own lived contradictions.

${ }^{39}$ Cited in Carpenter, WH Auden: A Biography, 207

${ }^{40}$ W. H. Auden, 'Men of Thought and Action', October 1938, in Prose I, 458.

${ }^{41}$ Auden, The English Auden, 246. The 'folded lie' presumably refers, in the first instance, to newspaper propaganda, which implies there is still an interventionist role for the poet. This stanza, too, would eventually be excised.

${ }^{42}$ Auden, 'The People v. the Late Mr William Butler Yeats', 393.

${ }^{43}$ Rachel Galvin, 'Stevens, Auden: Whose Age Was it Anyway - and Why Do We Care?', Wallace Stevens Journal $37: 2$ (2013), 155-65 (162).

${ }^{44}$ Auden, 'The People v. the Late Mr William Butler Yeats', 393. 